\title{
IN VITRO SHOOT REGENERATION OF SWALLOW ROOT (DECALEPIS HAMILTONII) - A STENO-ENDEMIC RED LISTED MEDICINAL PLANT
}

\author{
MANJULA RANGANATHA ${ }^{1}$, ANNAPURNA AS ${ }^{2}$, ASHWANI SHARMA ${ }^{1}$, NAGASHREE N RAO ${ }^{1 *}$ \\ ${ }^{1}$ Department of Biotechnology, RV College of Engineering, Visvesvaraya Technological University, Belagavi, Karnataka, India. ${ }^{2}$ Department \\ of Botany, Jnanabharathi Campus, Bangalore University, Bengaluru, Karnataka, India. Email: nagashreenrao@rvce.edu.in
}

Received: 27 December 2019, Revised and Accepted: 14 February 2020

\section{ABSTRACT}

Objective: In vitro shoot regeneration of Decalepis hamiltonii Wight \& Arn. is an endangered endemic medicinal plant using biotechnological interventions and to conserve this threatened species.

Methods: In the present study, various explants such as shoot tip, leaf, and nodal segments were inoculated on Murashige and Skoog media augmented with different hormonal regimes of auxin and cytokinin combinations, namely, naphthalene acetic acid (NAA), indole-3-acetic acid (IAA), benzyl adenine (BAP), 6-( $\gamma, \gamma$-Dimethylallylamino)purine (2iP), and triacontanol (TRIA).

Results: Direct regeneration of shoots obtained in $3.0 \mathrm{mg} / \mathrm{l} 2 \mathrm{iP}$ alone and in combination with $0.1 \mathrm{mg} / \mathrm{lAA}$ and/or $1.0 \mathrm{mg} / \mathrm{l} \mathrm{BAP}$ exhibited the best response with average shootlet length being $6.5 \pm 0.17-8.0 \pm 0.92 \mathrm{~cm}$, respectively, and percentage response was between $68 \%$ and $75 \%$. The callus induced regeneration was obtained from both nodal and leaf explants with maximum response (85\%) observed in combination of (2.0 mg/l) 2iP, (1.0 mg/l) IAA and (2.0 mg/l) kinetin with multiple shoots showing mean shoot number of 1.83 and average shootlet length of $6.3 \pm 0.19 \mathrm{~cm}$.

Conclusions: The current research provides a competent in vitro propagation method for Decalepis which could be commercialized for developing identical plants with good mass multiplication rate and for better conservation of the germplasm.

Keywords: Regeneration, Decalepis, 2-Hydroxy-4-methoxybenzaldehyde, Apocynaceae, 6-( $\gamma, \gamma$-Dimethylallylamino)purine.

(c) 2020 The Authors. Published by Innovare Academic Sciences Pvt Ltd. This is an open access article under the CC BY license (http://creativecommons. org/licenses/by/4. 0/) DOI: http://dx.doi.org/10.22159/ajpcr.2020.v13i4.36714

\section{INTRODUCTION}

In recent years, in vitro plant regeneration or biotechnological interventions are exceptionally benevolent in conserving endangered, endemic medicinal plants with high prudent significance. Decalepis hamiltonii Wight \& Arn. (Apocynaceae) is a monotypic species of the genus Decalepis, steno-endemic to Western Ghats of India and the Deccan Peninsula. The wild destructive harvesting of medicinally significant, tuberous fleshy roots of $D$. hamiltonii has threatened its extinction and has been included recently in IUCN Red List [1,2].

D. hamiltonii is a conglomeration of biomolecules with antioxidant activity and a well-known source for edible plant nutraceuticals. Decalepis is well recognized for its potential application as antidiabetic, hepatoprotective, antiatherosclerotic, antimicrobial, and in the treatment of other ailments [3,4]. The bioactive compounds present in D. hamiltonii have not been explored [5]. The dry roots of Decalepis sp. is envisaged for the production of various bioactive compounds; key component being a flavoring compound, 2-Hydroxy-4-methoxybenzaldehyde (2-HMB) (96.29\%) with other essential oils [6] and adjuvants in traces [4]. In recent years, many efforts have been documented on micropropagation and regeneration of this important genus, but the recalcitrant nature has led to meager reproducibility. In vitro regeneration [7-9] in D. hamiltonii is meager because of its genotype specificity. Tissue culture plants of $D$. hamiltonii have been reported to enhanced levels of 2-HMB in the roots [9]. Hence, the current research was undertaken to demonstrate the in vitro regeneration capability of $D$. hamiltonii through direct and indirect regeneration methods.

\section{METHODS}

Culture conditions for callus induction, direct and indirect regeneration

D. hamiltonii is an endangered plant, endemic to Western Ghats of India. Decalepis mother plant was obtained from the Foundation for Revitalization of Local Health Traditions, Bengaluru. For in vitro regeneration healthy nodal segments, shoot tip and young tender leaves were used as explants. The explants were initially washed under running tap water for 30 min with few drops of Tween 20 and were treated with 1\% Bavistin (carbendazim 50\% WP) for 30 min. After thorough washing in distilled water to remove fungicide, explants were surface sterilized aseptically for a minute with mercuric chloride $(0.1 \%)$ followed by several washes with autoclaved distilled water. The explants were finally sterilized with $70 \%$ alcohol (v/v) for $30 \mathrm{~s}$ along with thorough wash in sterile distilled water. The explants were further cultured on Murashige and Skoog (MS) medium supplemented with various hormonal regimes [10].

\section{Direct regeneration}

For direct regeneration, nodal and shoot tip explants were selected and cultured initially on basal MS medium supplemented with varied concentrations of benzyl adenine (BAP) $0-5 \mathrm{mg} / \mathrm{l}, 0.1 \mathrm{mg} / \mathrm{l}$ naphthalene acetic acid (NAA), and $5.0 \mu \mathrm{g} / \mathrm{l}$ triacontanol (TRIA) (Table 1). All the cultures were maintained at $26 \pm 2^{\circ} \mathrm{C}$ under white fluorescent light with $16 / 8 \mathrm{~h}$ photoperiod and subcultured regularly at 3 weeks interval.

\section{Indirect regeneration}

For indirect regeneration, young tender leaf and nodal explants were used as the explants and were cultured on MS basal medium augmented with different concentration of auxins, $1 \mathrm{mg} / \mathrm{l}$ indole-3- acetic acid (IAA), $0.1 \mathrm{mg} / \mathrm{l} \mathrm{NAA}$, and cytokinins $2-4 \mathrm{mg} / \mathrm{l} 6-(\gamma, \gamma$-Dimethylallylamino $)$ purine (2iP), $2 \mathrm{mg} / \mathrm{l}$ kinetin, 1-7 mg/l BAP, and $6 \mathrm{mg} / \mathrm{l}$ zeatin. The callus obtained from leaf and nodal explants after inoculation for a period of 20-25 days was further subcultured on shoot regeneration medium with MS medium supplemented with various concentrations of plant growth regulators (Table 2). Initially, cultures were maintained in dark for a week and later shifted to white fluorescent light with $16 / 8 \mathrm{~h}$ photoperiod at $26 \pm 2^{\circ} \mathrm{C}$ with regular subculturing at every 3 weeks. 
Table 1: Effect of plant growth regulators on in vitro direct regeneration of Decalepis hamiltonii from nodal explants

\begin{tabular}{|c|c|c|c|c|c|}
\hline \multicolumn{4}{|c|}{ Plant growth regulators } & \multirow[t]{2}{*}{$\%$ response } & \multirow[t]{2}{*}{ Mean length of shoot $(\mathrm{cm})$} \\
\hline NAA (mg/l) & BAP (mg/l) & $2 \mathrm{iP}(\mathrm{mg} / \mathrm{l})$ & Zeatin $(\mu \mathrm{g} / \mathrm{l})$ & & \\
\hline 0.1 & - & - & - & 48 & $4.0 \pm 0.42$ \\
\hline 0.1 & 0.1 & - & - & 65 & $4.8 \pm 0.52$ \\
\hline 0.1 & 0.5 & - & - & 70 & $6.7 \pm 0.45$ \\
\hline 0.1 & 1.0 & - & - & 68 & $4.8 \pm 1.13$ \\
\hline 0.1 & 2.0 & - & - & 67 & $3.2 \pm 0.45$ \\
\hline 0.1 & 3.0 & - & - & 55 & $1.8 \pm 0.24$ \\
\hline 0.1 & 4.0 & - & - & 40 & $1.6 \pm 0.38$ \\
\hline 0.1 & 5.0 & - & - & 57 & $5.0 \pm 0.29$ \\
\hline 0.1 & 1.0 & 3.0 & - & 75 & $8.0 \pm 0.92$ \\
\hline- & 7.0 & - & - & 35 & $2.1 \pm 0.02$ \\
\hline 0.1 & - & 3.0 & - & 68 & $6.5 \pm 0.17$ \\
\hline - & - & 2.0 & - & 70 & $6.8 \pm 0.34$ \\
\hline 0.1 & - & - & 6.0 & 42 & $8.3 \pm 0.88$ \\
\hline
\end{tabular}

Table 2: Effect of plant growth modulators on in vitro indirect regeneration of Decalepis hamiltonii from leaf and nodal explants

\begin{tabular}{|c|c|c|c|c|c|c|c|c|c|}
\hline \multicolumn{7}{|c|}{ Plant growth regulators } & \multirow{2}{*}{$\begin{array}{l}\% \\
\text { response }\end{array}$} & \multirow{2}{*}{$\begin{array}{l}\text { Mean number } \\
\text { of shoot }\end{array}$} & \multirow{2}{*}{$\begin{array}{l}\text { Mean length } \\
\text { of shoot }(\mathrm{cm})\end{array}$} \\
\hline NAA (mg/l) & IAA (mg/l) & BAP (mg/l) & TRIA $(\mu \mathrm{g} / \mathrm{l})$ & $2 \mathrm{iP}(\mathrm{mg} / \mathrm{l})$ & Zeatin (mg/l) & Kinetin (mg/l) & & & \\
\hline 0.1 & - & 1.0 & - & - & - & - & 75 & 1 & $6.0 \pm 0.92$ \\
\hline 0.1 & - & 2.0 & - & - & - & - & 63 & 1 & $4.3 \pm 0.21$ \\
\hline 0.1 & - & 3.0 & - & - & - & - & 45 & 1 & $2.8 \pm 0.13$ \\
\hline 0.1 & - & 0.2 & 5.0 & - & - & - & 79 & 1 & $5.0 \pm 0.25$ \\
\hline 0.1 & - & 0.3 & 5.0 & - & - & - & 82 & 1 & $5.5 \pm 0.41$ \\
\hline 0.1 & 00 & 7.0 & - & - & - & - & 35 & 1 & $2.1 \pm 0.02$ \\
\hline 0.1 & - & - & - & - & 6.0 & - & 45 & 1 & $6.0 \pm 0.88$ \\
\hline- & - & - & - & 2.0 & - & - & 84 & 1 & $6.5 \pm 0.05$ \\
\hline - & - & - & - & 3.0 & - & - & 68 & 1 & $6.3 \pm 0.87$ \\
\hline - & - & - & - & 4.0 & - & - & 72 & 1 & $5.5 \pm 0.28$ \\
\hline - & 1.0 & - & - & 2.0 & - & 2.0 & 85 & 1.8 & $6.2 \pm 0.19$ \\
\hline - & 1.0 & 2.0 & - & - & - & 2.0 & 66 & 1 & $4.2 \pm 0.21$ \\
\hline
\end{tabular}

Mean length of shoot (cm): (Mean \pm standard error) after 8 weeks inoculation to shooting medium. NAA: Naphthalene acetic acid, IAA: Indole-3-acetic acid, BAP: Benzyl adenine, TRIA: Triacontanol, 2iP: 6- $(\gamma, \gamma$-Dimethylallylamino $)$ purine

\section{Statistical analysis}

The experiments were repeated thrice with 10 explants for each combination. Analysis of variance and mean separations were carried out using Tukey's test at $0.05 \%$ level of significance.

\section{RESULTS AND DISCUSSION}

In recent years, $D$. hamiltonii has been red listed as endangered and endemic plant. The presence of economically important bioactive compounds in Decalepis has been the reason for its continuous and extensive exploitation. Hence, the need of an hour is to conserve this important medicinal plant from being extinct, so in vitro culture technique offers an alternative strategy to conserve this endangered endemic plant [11]. The development of efficient in vitro micropropagation method emphasizes a prime role in crop improvement. In the current manuscript, a reproductive, commercially viable plant regeneration method was optimized for $D$. hamiltonii using cytokinins and auxins based plant growth regulators.

The direct plant regeneration was observed from both nodal explants and shoot tip explants. Shoot induction was recorded after 8 weeks of culturing. All the hormonal compositions studied, responded to shoot regeneration on MS medium along with supplements. The different concentrations of $0.1-7 \mathrm{mg} / \mathrm{lBAP}$ were used in combination with $0.1 \mathrm{mg} / \mathrm{l}$ NAA (Fig. 1). The BAP concentrations of 0.1 and $0.5 \mathrm{mg} / \mathrm{l}$ along with NAA $0.1 \mathrm{mg} / \mathrm{l}$ resulted in $65 \%$ and $70 \%$ regeneration response with mean shoot length of $6.7 \pm 0.45 \mathrm{~cm}$ and $4.8 \pm 1.13 \mathrm{~cm}$, respectively (Table 1 ), and BAP is the most frequently used synthetic cytokinins supplement in plant regeneration protocols. The combinations of cytokinins are reported to be best in many studies for the induction of axillary shoots [11].
Veerabathini et al. [12] observed maximum friable callus development in Catharanthus roseus on the MS medium supplemented with $1.0 \mathrm{mg} / \mathrm{L}$ BAP+1.0 mg/L NAA. The combination of BAP with indolebutyric acid is proved best in direct regeneration response in micropropagation of many plants like Aloe vera [13]. In line with our findings, Saritha and Naidu [14] also obtained adventitious shoots directly from leaf explants of Spilanthes acmella, on the MS media incorporated with $1.0 \mathrm{mg} / \mathrm{l}$ BAP and $0.1 \mathrm{mg} / \mathrm{l}$ NAA combination and similarly in Ceropegia bulbosa Roxb. (Asclepiadaceae) [15]. Correspondingly, multiple shoot regenerations were observed in $3.0 \mathrm{mg} / \mathrm{l} \mathrm{BAP}$ and $0.5 \mathrm{mg} / \mathrm{l} \mathrm{NAA}$ from leaf and nodal explants in Centella asiatica L. [16]. With the increased concentration of $7 \mathrm{mg} / \mathrm{l} \mathrm{BAP}$, the percentage of shoot response was decreased (42\%) (Table 1). The shoot tip culture when inoculated on MS medium with $6 \mathrm{mg} / \mathrm{l}$ zeatin (Fig. 1e), the length of the shoot reported was $8.3 \pm 0.88 \mathrm{~cm}$, but the percentage of response was low (42\%). Ravanfar et al. [17] obtained a direct in vitro shooting in cabbage with $2 \mathrm{mg} / \mathrm{l}$ zeatin and in sweet potato cv. Brondal using $0.2 \mathrm{~g} / \mathrm{l}$ zeatin [18]. Augmentation of $2.0 \mathrm{mg} / \mathrm{l} 2 \mathrm{iP}$ alone (Fig. 1a) and in combination with $1.0 \mathrm{mg} / \mathrm{l}$ BAP and/or $0.1 \mathrm{mg} / \mathrm{l} \mathrm{NAA} \mathrm{(Fig.} \mathrm{1c} \mathrm{and} \mathrm{1f)} \mathrm{in} \mathrm{the} \mathrm{regeneration} \mathrm{media}$ showed best results in terms of average shoot length being $6.5 \pm 0.17$ $8.0 \pm 0.92 \mathrm{~cm}$ and also percentage response $68-75 \%$ both single and multiple shoots from a single node (Table 1). Shinde et al. [19] observed that MS media incorporated with $2.5 \mu \mathrm{M}$ BAP and $7.5 \mu \mathrm{M} 2 \mathrm{iP}$ produced highest frequency $83.3 \%$ of regenerated adventitious shoots from callus cultures of Artemisia nilagirica var. nilagirica (Indian wormwood), and in Pterocarpus santalinus, $2.5 \mu \mathrm{M}$ BAP and $2 \mu \mathrm{M} 2 \mathrm{iP}$ gave the same trend for regeneration [20].

Callus-based indirect regeneration was obtained from nodal and leaf explants of D. hamiltonii (Table 2). The maximum response toward 

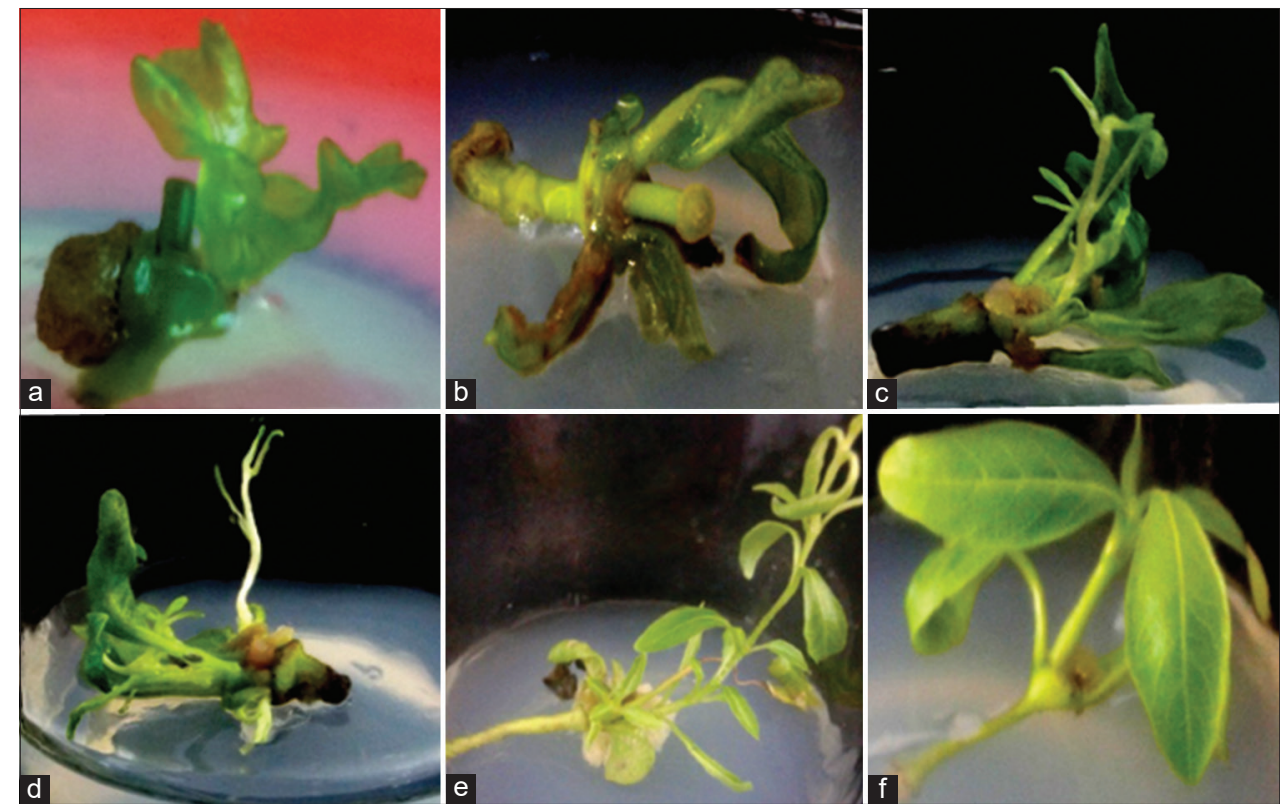

Fig. 1: In vitro direct regeneration of Decalepis hamiltonii from shoot tip and nodal culture. (a) Shoot regeneration from nodal culture on $2 \mathrm{mg} / \mathrm{l}$ 6-( $\gamma, \gamma$-Dimethylallylamino)purine (2iP) supplemented Murashige and Skoog (MS) medium, (b) adventitious shoot induced from nodal explant grown on MS medium supplemented with $7 \mathrm{mg} / \mathrm{l}$ benzyl adenine (BAP), (c) multiple shoot induction from shoot tip explant on MS medium with $1 \mathrm{mg} / \mathrm{l} \mathrm{BAP}+3 \mathrm{mg} / \mathrm{l} 2 \mathrm{iP}$, (d) direct regeneration from shoot tip explant grown on MS medium $3 \mathrm{mg} / \mathrm{l} 2 \mathrm{iP}+0.1 \mathrm{mg} / \mathrm{l}$ NAA, (e) 6 mg/l zeatin+0.1 mg/l NAA, (f) 3 mg/l 2iP+0.1 mg/l NAA+1 mg/l BAP
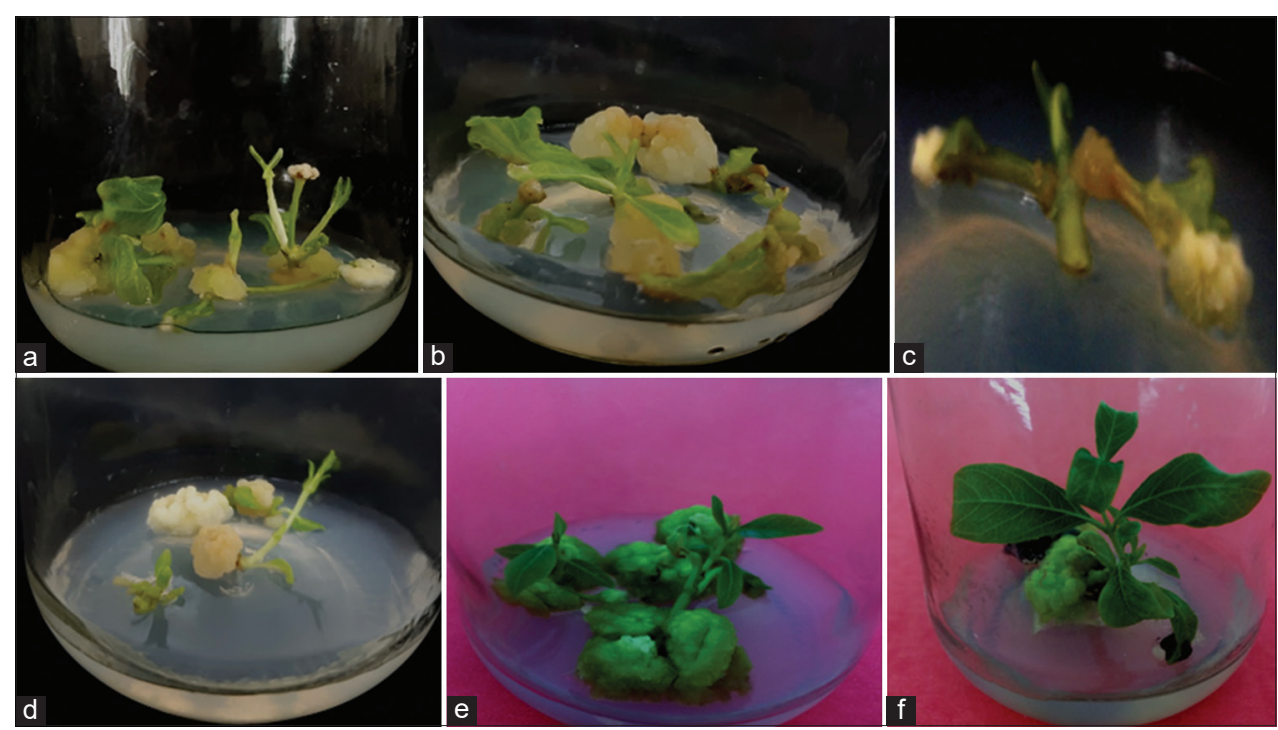

Fig. 2: In direct regeneration in Decalepis hamiltonii from leaf and nodal explants from MS basal media augmented with various hormonal regime, (a) multiple shoots from $2 \mathrm{mg} / \mathrm{l}$ 6-( $\gamma, \gamma$-Dimethylallylamino)purine (2iP) $+2 \mathrm{mg} / \mathrm{l} \mathrm{Kin}+1 \mathrm{mg} / \mathrm{l}$ indole-3-acetic acid (IAA), (b) shoot

induction from nodal explant on $2 \mathrm{mg} / 12 \mathrm{iP}$, (c) nodal explant grown on Murashige and Skoog medium with $5 \mu \mathrm{g} / \mathrm{l}$ triacontanol and

$0.3 \mathrm{mg} / \mathrm{l}$ benzyl adenine (BAP) shows shoot initiation and callus induction, (d) shoot initiation from leaf callus on $2 \mathrm{mg} / 1 \mathrm{BAP}+2 \mathrm{mg} / \mathrm{l}$ Kin+1 mg/l IAA, (e) and (f) shoot regeneration from nodal tissue callus on $3 \mathrm{mg} / \mathrm{l} 2 \mathrm{iP}$ and $4 \mathrm{mg} / \mathrm{l} 2 \mathrm{iP}$, respectively

regeneration $(82 \%)$ was observed in combination of $0.1 \mathrm{mg} / \mathrm{l} \mathrm{NAA}$, $0.3 \mathrm{mg} / \mathrm{l} \mathrm{BAP}$, and $5 \mu \mathrm{g} / \mathrm{l}$ TRIA with little growth (Fig. $2 \mathrm{c}$ and d ). Verma et al. [21] have evaluated good impact of $2 \mathrm{mg} / \mathrm{l} \mathrm{TRIA} \mathrm{in} \mathrm{combination}$ with $3 \mathrm{mg} / \mathrm{l} \mathrm{BAP}$ on in vitro shoot multiplication potential of Arachis hypogaea L. Many studies have reported TRIA-mediated complete crop improvement in terms of growth, enhanced enzyme activities, photosynthesis, yield, and nitrogen fixation [22]. In the present study, MS media with $0.1 \mathrm{mg} / \mathrm{l} \mathrm{NAA}$ and $1.0 \mathrm{mg} / \mathrm{l}$ BAP gave a single shoot per explant with $75 \%$ of response with mean length of $6.0 \pm 0.92 \mathrm{~cm}$. Among various concentrations of $2 \mathrm{iP}$, namely, 2, 3, and $4.0 \mathrm{mg} / \mathrm{l}$ for shoot bud regeneration, shooting response exhibited was $8484 \%$ (Fig. 2b), 68\% (Fig. 2e) and 72\% (Fig. 2f), respectively. The combination of $2.0 \mathrm{mg} / \mathrm{l}$ kinetin and $1.0 \mathrm{mg} / \mathrm{l}$ IAA with $2.0 \mathrm{mg} / \mathrm{l} 2 \mathrm{PP}$ (Fig. 2a) produced multiple shoots with an average shoot of 1.83 per explants and response of $85 \%$ showing mean length of $6.3 \pm 0.19 \mathrm{~cm}$ on par with the other combinations studied (Table 2). In line with our results, shoot regeneration of wheat (Triticum aestivum L.) was maximum in MS media containing hormonal combination of $0.5 \mathrm{mg} / \mathrm{l} 2 \mathrm{iP}, 0.4 \mathrm{mg} / \mathrm{l}$ kinetin, and (0.1 mg/l) IAA [23]. Kinetin has proved to increase the shoot number alone or in combination with BAP or IAA in an important nootropic plant Bacopa monnieri (L) Pennell [24]. The fortification of $2.0 \mathrm{mg} / \mathrm{l}$ kinetin and $1 \mathrm{mg} / \mathrm{l}$ BAP in MS medium produced maximum shoots in Gymnema sylvestre Br. [25]. However, similar composition with $2 \mathrm{mg} / \mathrm{l}$ BAP had regeneration response of $66 \%$ proving that the 
addition of two cytokinins aids in indirect regeneration (Fig. 2d). In vitro organogenesis depends on the application of exogenous plant growth regulators. The cytokinin BAP individually $1.0 \mathrm{mg} / \mathrm{l}$ also proved $100 \%$ efficient in producing maximum shoot proliferation response in Thevetia neriifolia [26]. The efficiency of BAP in inducing adventitious shoots over kinetin was reported in Hemidesmus indicus [27] and $C$. bulbosa [28]; auxins and cytokinins are able to bring shoot or root formation from callus, but the effective concentrations of these growth regulators may vary. The combination of auxin and cytokinin was found to be effective for shoot bud formation from callus in Tylophora indica [29] and C. bulbosa [28].

\section{CONCLUSIONS}

This investigation provides a competent protocol for genetically reliable shoot induction by supplementation of cytokinins, auxin, and other adjuvants along with callus initiation and proliferation of D. hamiltonii a recalcitrant and steno-endemic plant. The current research bestows a proficient in vitro propagation method which could be commercialized for developing identical plants with good mass multiplication rate and to conserve germplasm. Further, this study can be extended to overexpress the biosynthetic gene in callus or suspension culture to enhance pharmaceutically and nutraceutically valuable specific secondary metabolites.

\section{ACKNOWLEDGMENT}

The authors would like to thank the Department of Biotechnology (DBT), Government of India, for financial support and extend concede to RSST and Rashtreeya Vidyalaya College of Engineering, Bengaluru (affiliated to Visvesvaraya Technological University, Belagavi), for providing R\&D support and encouragement.

\section{AUTHORS' CONTRIBUTIONS}

Nagashree N Rao and Ashwani Sharma designed research; Manjula Ranganatha and Annapurna AS performed research; Nagashree N Rao, Ashwani Sharma, and Manjula R analyzed data; Nagashree N Rao, Manjula R, and Ashwani Sharma wrote the paper.

\section{CONFLICTS OF INTEREST}

The authors declare no conflicts of interest.

\section{SOURCE OF FUNDING}

DBT - Government of India.

\section{REFERENCES}

1. Ved D, Saha D, Ravikumar K, Haridasan K. Decalepis hamiltonii. The IUCN Red List of Threatened Species, PaperNo. T50126587A50131330; 2015.

2. Mishra P, Kumar A, Sivaraman G, Shukla AK, Kaliamoorthy R, Slater A, et al. Character-based DNA barcoding for authentication and conservation of IUCN red listed threatened species of genus Decalepis (Apocynaceae). Sci Rep 2017;7:14910.

3. Sharma S, Shahzad A. An overview on Decalepis: A genus of woody medicinal climbers. J Plant Sci Res 2014;1:104

4. Nagarajan SL, Rao JM, Gurudatta KN. Chemical composition of the volatiles of Decalepis hamiltonii Wight and Arn. Flavour Frag J $2001 ; 16: 27-9$.

5. Rathi N, Harwalkar K, Jayashree V, Sharma A, Rao NN. 2-hydroxy-4-methoxybenzaldehyde, an astounding food flavoring metabolite: A review. Asian J Pharm Clin Res 2017;10:105-10.

6. Sreelekha M, Jirovetz L, Shafi PM. Comparative study of the essential oils from Hemidesmus indicus and Decalepis hamiltonii. Asian J Chem 2007;19:4942-4.
7. George J, Bais HP, Ravishankar GA, Manilal P. Optimization of media constituents for shoot regeneration from leaf callus cultures of Decalepis hamiltonii Wight and Arn. Hortic Sci 2000;35:296-9.

8. Bais HP, Sudha G, Suresh B, Ravishankar GA. Silver nitrate influences in vitro root formation in Decalepis hamiltonii Wight and Arn. Curr Sci 2000;79:894-8.

9. Giridhar P, Rajasekaran T, Nagarajan S, Ravishankar GA. Production of 2-hydroxy-4-methoxybenzaldehyde in roots of tissue culture raised and acclimatized plants of Decalepis hamiltonii Wight and Amp., an endangered shrub endemic to Southern India and evaluation of its performance Vis-a-Vis plants from natural habitat. Indian J Exp Biol 2004;42:106-10.

10. Murashige T, Skoog FA. Revised medium for rapid growth and bio assays with tobacco tissue cultures. Physiol Plant Physiol Plant 1962;15:473-9.

11. Parzymies M, Dabski M. The effect of cytokinin types and their concentration on in vitro multiplication of Clematis viticella L. and Clematis integrifolia petit faucon. Acta Sci Pol Hortorum Cultus 2012;11:81-91

12. Veerabathini S, Sarang S, Shalini S, Deepa SP. Standardization of friable callus development in Catharanthus roseus Linn. Int J Pharm Pharm Sci 2015;7:111-13.

13. Shukla N, Rao NN, Sharma A. Micropropagation and elicitation studies in Aloe vera. Asian J Pharm Clin Res 2016;9:54-60.

14. Saritha KV, Naidu CV. Direct shoot regeneration from leaf explants of Spilanthes acmella. Biol Plant 2008;52:334-8.

15. Phulwaria M, Shekhawat NS, Rathore JS, Singh RP. An efficient in vitro regeneration and ex vitro rooting of Ceropegia bulbosa Roxb. Ind Crops Prod 2013;42:25-9.

16. Mohapatra H, Barik DP, Rath SP. In vitro regeneration of medicinal plant Centella asiatica. Biol Plant 2008;52:339.

17. Ravanfar SA, Karimi E, Mehrabanjoubani P, Ebrahimi M. Enhancement of phenolic and flavonoids compounds, antioxidant and cytotoxic effects in regenerated red cabbage by application of zeatin. Nat Prod Res 2020;34:898-902.

18. Masekesa TR, Gasura E, Ngadze E. Efficacy of zeatin kinetin and thidiazuron in induction of adventitious root and shoot from petiole explants of sweet potato cv Brondal. S Afr J Bot 2016;104:1-5.

19. Shinde S, Sebastian JK, Jain JR, Hanamanthagouda MS, Murthy HN. Efficient in vitro propagation of Artemisia nilagirica var. nilagirica (Indian Wormwood) and assessment of genetic fidelity of micropropagated plants. Physiol Mol Biol Plants 2016;22:595-603.

20. Rajeswari V, Paliwal K. In vitro plant regeneration of red sanders Pterocarpus santalinus L. f. from cotyledonary nodes. Indian J Biotechnol 2008;7:541-6.

21. Verma A, Malik CP, Gupta VK, Bajaj BK. Effects of in vitro triacontanol on growth antioxidant enzymes and photosynthetic characteristics in Arachis hypogaea L. Braz J Plant Physiol 2011;23:271-7.

22. Naeem M, Khan A, Masroor M, Moinuddin MM. Triacontanol: A potent plant growth regulator in agriculture. J Plant Interact 2012;7:129-42.

23. Rashid U, Ali S, Ali GM, Ayub N, Masood MS. Establishment of an efficient callus induction and plant regeneration system in Pakistani wheat Triticum aestivum cultivars. Electron J Biotechnol 2009;12:1-2.

24. Rao NN, Umesh TG, Sharma A. Regeneration potential and major metabolite analysis in nootropic plant-Bacopa monnieri L. Pennell. Asian J Pharm Clin Res 2014;7:134-6.

25. Syedy M, Nama KS. In vitro propagation of shoots and callus induction of Gymnema sylvestre R. Br. an important anti-diabetic plant. Int J Curr Pharm Res 2018;10:60.

26. Ibrahim N, Padikkala J, Mathew L. In vitro plant regeneration of Thevetia neriifolia Juss from internode explants via indirect organogenesis. Int J Pharm Pharm Sci 2014;7:169-72.

27. Sreekumar S, Seeni S, Pushpangadan P. Micropropagation of Hemidesmus indicus for cultivation and production of 2-hydroxy-4methoxy-benzaldehyde. Plant Cell Tissue Organ Cult 2000;62:211-8.

28. Britto SJ, Natarajan E, Arockiasamy DI. In vitro flowering and shoot multiplication from nodal explants of Ceropegia bulbosa Roxb var bulbosa. Taiwania 2003;48:106-11.

29. Faisal M, Gill S, Anis M. In vitro regeneration and plant establishment of Tylophora indica burm. In Vitro Cell Dev Biol Plant 2005;41:511-15. 